\title{
Saxony's reforms a model for Germany?
}

Dresden. The east German state of Saxony has broken ranks with its neighbours by introducing legislation that will cause radical changes in the way its universities are run. In particular, the new law will establish for the first time in Germany a system that places strong emphasis on selecting students, monitoring the research and teaching performance of staff, and encouraging competition between university departments.

The new law was passed by the state parliament last month, and takes effect on German reunification day, 3 October. This is the date by which the reorganization of higher education in the five new Länder must be completed; legislation passed by the four others does little more than bring local educational systems into line with their west German counterparts.

Saxony has taken a different path. Its goal, says Hans Joachim Meyer, Saxony's Minister for Science and Art, is to avoid repeating the mistakes of west Germany, where universities are overcrowded and inefficient, and students (whose average age at graduation is 28 ) stay too long.

One of the most revolutionary reforms introduced by Meyer - who was also education minister in Lothar de Maizière's shortlived post-Honnecker government in the former German Democratic Republic - is a new admission procedure. German universi- ties traditionally guarantee a place on the course of his or her choice to any student who achieves a certain average grade in the school-leaving certificate, the Abitur. Meyer's new act gives each university the right to select students on the basis of performance in specific subjects, and therefore to stipulate course entry requirements.

Universities will also be allowed to conduct their own entrance examinations. "It is, after all, unreasonable to expect a university to open its doors to absolutely everyone who wants in", says Meyer. Universities will be allowed to require students to leave if they do not complete their final examinations within four semesters of the normal duration of a course of study.

Keen to improve overall efficiency, Meyer has stipulated that reviews of the quality of research and teaching should be carried out each year. Research will be assessed according to the number of research projects undertaken, the amount of external funding raised and the number of scientific papers published, as well as an independent evaluation of its general merits.

The assessment of teaching will be based on the number of teaching hours and on both the content and quality of instruction, with appropriate input from students. The results of these reviews will be used to amend an individual's research funding; in some circumstances, if a whole faculty is found to be performing poorly, it may be used to reduce staff numbers.

The power balance within universities will also shift. Meyer wants to strengthen the position of rectors and deans so that they are free to make major decisions, and to make a clearer separation of decision-making between academic and administrative matters. A new independent supervisory board for each university will be set up in conjunction with the ministry. This board will conduct its own evaluations of the administration and general facilities of universities.

Meyer's initiative has the support of many in west Germany. Gerhard Neuweiler, head of Germany's science advisory body (the Wissenschaftsrat), says that Meyer's plan coincides closely with the Wissenschaftsrat's own recommendations on university reforms, published earlier this year. "Saxony is the first to make a real fresh start", says Neuweiler.

But the initiative also has strong critics, in particular Saxony's socialists, who believe it is based on non-democratic principles. They complain that all committees with decision-making powers will be dominated by professors, and that university deans and the science minister have been given the right to "reign supreme in the universities", in apparent contradiction of the universities' constitutional laws.

Meyer himself would like to see his model adopted elsewhere in Germany. He realizes that this will require a consensus among his counterparts in Germany's other 15 states, but is optimistic that this can be achieved.

Robert Unterhuber

\section{Earmarks all over the place, report finds}

Washington. Attempts to set sensible research priorities for the United States are likely to be wrecked by earmarking practices that direct funds to congressmen's pet projects, says a report prepared by George Brown (Democrat, California), chairman of the Science, Space and Technology Committee of the House of Representatives.

"Politics as usual, in its most self-serving form, will destroy [efforts] to ensure that our research agenda meets priority needs and invests our scarce resources wisely," says the report, which attacks the earmarking process on the basis of evidence gathered from 50 universities that received funding last year for earmarked projects.

As chairman of an 'authorization' committee, whose job it is to examine issues in detail before laying out spending priorities, Brown has cause to resent the growing tendency of the more powerful 'appropriations' committees - which actually spend the money - to earmark funds at the last minute for projects favoured by particular congressmen. The practice-science's own branch of pork-barrel politics - has recently grown out of control, with the amount earmarked expanding from \$248 million in 1989 to $\$ 763$ million last year. Most of this is for the construction of new research buildings at universities.

The report, which will be subject to hearings by Brown's committee in September, argues that:

- A short list of schools with "friends in high places", headed by Iowa State University, the University of Alaska and Oregon Health Sciences University, persistently get the lion's share of earmarked funds.

- The process leads to "perverse outcomes" in federal agency responsibility, with, for example, the Department of Energy engaged in hospital building.

Recipients commonly pay Washington lobbyists retainers of up to $\$ 50,000$ a month to exert influence.

- Earmarked projects are seldom subject to peer review. One respondent said that while its science might be free from peer review, the building to house it would be "subject to review by an independent team of architects".

Introducing the report, Brown acknowledges that it "runs the risk of offending respected colleagues in the House or Senate". This is undoubtedly true: after complaints from powerful congressmen, an earmarking report published last autumn by the Congressional Research Service has just been withdrawn and re-released in more anodyne form, no longer even referring to 'earmarking' by name.

Brown's attempts to restrict the right of long-standing congressmen to tip a few million dollars in the direction of schools in their districts are unlikely to win him friends on Capitol Hill. And some universities see earmarking as a necessary evil, given the paucity of funding for new buildings from any other federal source. The National Science Foundation (NSF), for example, which funds $\$ 3$ billion of research in the physical sciences each year, had less than $\$ 40$ million last year to spend on new facilities.

Brown wants more money appropriated to agencies like NSF and less distributed directly by congressmen through earmarking. No prizes, though, for guessing which option the appropriations committees will prefer when they return from recess next month to fix the budget. Colin Macilwain 